\title{
Effects of Capital Structure on Share Price Performance of Commercial Banks Listed in Nairobi Security Exchange, Eldoret, Kenya
}

\author{
Jane Chemutai $^{1}$, Dr.Caroline Ayuma ${ }^{2}$, Dr. Yusufkibet $^{3}$ \\ ${ }^{1}$ Department of Business, Faculty of Commerce,,KisiiUniversity, $P$ O Box 5760, post code 30100, Eldoret, Kenya, \\ ${ }^{2}$ Department of Business, Faculty of Commerce, Kisii University, P O Box 408 Kisii, Kenya, , \\ ${ }^{3}$ Department of Business, Faculty of Commerce, Kisii University, P O Box 408 Kisii, Kenya,
}

\begin{abstract}
The study aimed at investigating the effects of capital structure on the share-price performance on banks Listed on the Nairobi Security Exchange. It was guided by the following objectives; to find out the effect of debt on share price performance in banks listed in the Nairobi Security Exchange, to establish the effects of equity on share price performance in banks listed in the Nairobi Security Exchange, to assess the effect of bonds on share price performance in the banks listed in the Nairobi Security Exchange and to find out the effects of retained earnings on share price performance in the banks listed in the NSE..The study employed a descriptive research design for those companies which have gone public from 2009-2015. The target population comprised of the eleven cross listed banks in Kenya Nairobi Security Exchange. The branch managers and operations managers were selected to participate in the study using purposive sampling. The study employed census sampling technique in order to come up with the 11 banks to be studied since it was only cross listed financial institutions required. The researcher used questionnaires to collect data. The data collected was analyzed using descriptive methods and inferential statistics. Analysis of Variance and correlation was used to indicate the impact of the trends hypothesized to influence the performance. The findings from the analysis were organized, summarized and presented using tables. The study findings indicated that there was a significant relationship between all the study variables, debt, equity, bond and retained earnings on share price performance, The study recommends that, the commercial banks listed in Nairobi Security Exchange should formulate and enact a policy which makes commercial debt cheaper hence reduces cost of operations of banks.
\end{abstract}

Keywords: Debt, Equity, Bond, Retained Earnings and Share Price Performance

\section{Introduction}

Capital structure is a mixture of a various long-term equity shares and sources of funds including surpluses and reserves of an enterprise. A capital structure of an organization is the combination of its financial liabilities and its capital is usually uncertain but is a crucial resource for all firms, finance suppliers which are able to apply control over firms (Harris and Raviv, 1991). Equity and debt are the two main liabilities classes, with debt and equity proprietors acting on behalf of the two types of investors in the firm. Each of these is associated with different levels of risk, benefits, and control. The bank's ability to solve the needs of the stakeholders' is strongly linked to capital structure. In financial terms, is a way a firm will try to finance its own assets by combining equity and debt (Saad, 2010).

A firm's capital structure is then a composition or structures of its liabilities which affects the share prices performance of any organization. The level of share price has been considered very significant specifically as an alternative for market liquidity. Investment in securities is also significant to expansion a country's economy and corporate bodies in general. If there is a developed economic environment and managers and stakeholders in the corporate level have the positive expectations about the future, they would normally want to expand. This expansion can take many ways such as increase sales, an enlarged plant, and the acquisition of more powerful and modern equipment. Therefore, the suitable circumstances are expected to result to corporate performance (Mensah 2001).

Share price is usually used as a benchmark to gauge firm's performance and its variations as an pointer of the economic status, or otherwise, of a firm hence the need to be well-known with the indicators that could negatively affect share prices. Investment in equity shares is one of the major ways of investment that yields substantial returns to investors. It is also a financial capital source requirement of firms. Returns from equity investments are subject to differ because of the share prices movement, that depends on various indicators which could be firm specific and internal such as book value, dividends external indicators such as GDP, interest rate, 
Effects of Capital Structure on Share Price Performance of Commercial Banks Listed in Nairobi ....

government regulations, inflation and Foreign Exchange Rate (FOREX)and earnings per share.

Share prices and capital structure and are waved in international countries to influence the performance of firms. In a study done by Kheradyar and Ibrahim (2011) on China's stock market, the correlation between investment risk, return of equity and gains in share price in the construction industries and agricultural companies are closer, investment risk and the importance of gains in share price are much lower in comparison, but the financial sector of equity return is far higher than the two industries. Primary and secondary industries in the Chinese stock market have a powerful junction of the listed companies, investment risk and tertiary industry's gains in share price however they are not equivalent to its return on equity. Investors have undervalued as represented by the financial profitability of industries listed and it's better to invest in the companies in the primary and secondary. In Africa, capital structure has been established to impact the performance and in return profitability of a firm.

Due to the increasing spate of globalization, the influence of these occurrences have dropped down into the African banking sector hence banks in Africa have been affected by the changes and the banking services nature worldwide (Ahmed \&Rehman, 2008). Regardless of the developments made by banks, they are ranked on the foundation of their branch profitability, network and customer service. As the main roles of banks is to accumulate surplus funds and make them accessible to deficit sectors of the economy, they make profitable returns through borrowing and lending activities thus, the larger the bank size, then the more high the expenditure. The businesses in the East African Region, specifically Uganda and Kenya, are always on the look out to increase the debt finance in their capital structure, in expectation of improving their performance. The standard of escalating risk indicates that, with better debt the possibility for a decrease in gain is higher than the probability for an increase in gain and yet some of the firms usually use more debts than others and the organizations still perform even better. In Uganda, in the last decade, controls on credit and interest rates have been gradually eradicated so as to improve and enhance on the efficiency of allocation of financial resources and its mobilization.

\subsection{Statement of the Problem}

The decision of capital structure is critical for any organization in any given sector or economy. It is usually challenging for business firms to figure out the right mixture of equity and debt. The decision is significant because of the requirement to maximize returns to various organizational departments.

Ideally, the financial institutions growth in Kenya's active business environment depend on the management being able to successfully evaluate the appropriate and optimum capital mix that is needed to make sure that the shareholders acquire and achieve good returns. Financial institutions rely on their capability to assess, manage, monitor and identify risks in a sophisticated and sound way. In return to manage and assess risks, banks must have successful means of evaluating the suitable capital amount that is needed to attract losses that are unexpectedly arising from their credit, operational risk and market exposures. According to Ondiek (2010), postulated that capital structure of Kenyan listed companies is influenced by size, profitability and tangibility of assets.

Share prices are one of the major avenues of investment which gives higher returns to investors. A number of transactions take place every movement, it is very difficult for a common man to find out where to invest as they may be cheated by fraud companies and there is every chance of losing the heard earned money. The Returns from investments in equity are subject to differ, depending upon a variety of indicators such as the performance of the market conditions and certain stock, therefore knowledge of such factors and their possible impact on share prices is must, as it will help the investors to make wise investment decisions and enable firms to enhance their market value.

An overview of studies of factors affecting share prices has been presented in various literatures. Machel (2013) conducted a study on the effect of bond issues on the stock price performance of listed firms at the Nairobi Securities Exchange and came to a conclusion that bond issues do not have a significantly optimistic influence on the stock prices of issuing firms. Buigut et al. (2013) on their study on the link between share prices and capital structure in NSE assessed the effect of gearing ratio, debt and equity on share price and it is in light of these that the study activities to fill the gap by evaluating the effects of capital structure on share price performance.

\subsubsection{Effect of Debt on Share Price Performance}

\section{Literature Review}

While debt holders put on lesser control over the organization, and do not influence how the business is run, they earn a fixed rate of return and are protected by contractual obligations. The contractual responsibilities dictate what return is to be compensated for the finance and when it is unpaid. Equity holders are the remaining claimants of all the business' returns, knowing that most of the risk and having greater control decision making (Kochhar, 1997). 
Effects of Capital Structure on Share Price Performance of Commercial Banks Listed in Nairobi ....

Higher debt ratios could lead to optimistic management expectations and is associated with future cash flows. This therefore means that debt may result to shifts in the share prices of securities in a firm and hence have a general influence on the financial performance of a firm (Miller, 1985). According to Jensen (1986) debt has benefits for a company, for example it acts as a tax shield: interest payments usually are not taxable; hence the debt can increase the value of the firm which is another factor that benefits the debt disciplines managers (Jensen, 1986). Managers use open cash flows of the company to advance in projects, to pay dividends, or to hold on cash balance. But if the firm is not dedicated to some permanent payments like interest expenses, managers could have incentives to waste excess free cash flows. That is why, in order to punish managers, shareholders should attract debt. Besides, it is a common practice and procedure in agreements of debt between borrowers and banks to initiate some covenants of finance for firms.Managers cannot break these principles, and hence are bound to be more effective. In addition, the law usually guarantees a right of partial information disclosure to the company's debt holders, which acts as managers' supervision tool. As a result, measures of managers become more apparent, and they have more incentives to make higher value for the owners.

This is the essence of capital structure theory of Free Cash Flow Theory by (Jensen, 1986). A study done by Coricelli et al (2011) in Central and Eastern European companies showed hump-shaped link between the debt level and productivity growth. At the similar time, Majumdar and Chhibber (1999) found significantly negative effect of level of debt on firm performance, presenting the western corporate governance methods failure in transitions countries. Two classical empirical studies done by Harris and Raviv (1991) and Titman and Wessel (1988) lead to varied empirical results even in some of the fundamental facts about capital structure. Therefore, an empirical evidence of the link connecting leverage and firm performance is still not convincing.

Ross (1977) applied cherries and lemons intuition of Akerlof (1970) to a corporate arrangement problem. He measured the alternative of debt in signaling theory framework. Firms with less expected cash flows discover it extra costly to draw new debt. So, when the firm draws new debt, it entrusts itself to upcoming interest expenditure and indicates about its stable financial situation and capacity to make these expenditure in the future. Abor (2005) did a study on "capital structure and its effects on profitability, an empirical analysis of firms listed in Ghana", the study showed a significantly optimistic relation between the short-term debt ratio and profitability determined by ROE. However, an opposite link between debt ratio that is long-term and profitability was established.

Further the study show that extremely controlled MFIs achieve better by attaining out to more consumers, enjoy economies of scale, and therefore are capable of dealing with ethical hazard better and adverse selection. The study used panel data covering a ten year period, 1995-2004, and consists of 52 MFIs from Ghana. ROA and ROE is used as performance indicators, and total debt, short term debt and long term debt are used as indicators for capital structure of MFI. As control variables size, age and risk level are used (Kyereboah-Coleman, 2007). In the above review of literature, it is indicated that several studies have been done on debt financing and capital structure, others have payed attention on the link between capital structure and a firms performance, there was therefore no study reviewed on the effect of debt on share-price performance. This study therefore seeks to fill this gap.

\subsubsection{Effects of Equity on Share Price Performance}

Equity finance is that finance provided by the shareholders of the business and it is risky bearing finance. Equity finance holders own a percentage of the firm denominated in shares and they are entitled to a part of the profit of a business, recognized as a dividend. It is however, not mandatory to pay a dividend all the time as the company may retain the profits for financing expansion of its operations. Equity owners also share in the risks of the business and are the last to be important when a business is finished up after debt holders have been paid. Brealey and Myers (2003) explain capital structure as the mix of different securities of the firm.

The firm may issue dozens of different securities, but it attempts to find a mixture that makes the most of its overall market value by minimizing the cost of capital. When the firm is financed entirely by common stock, all its resultant cash flows will go to the stock holders. When it issues debt alongside the equity, the cash flows are shared between the common stockholders and the debt holders, with the debt holders getting a fixed amount, while the common stockholders get the residual amount depending on the overall performance of the business. Shuetrim, Lowe and Morling (1998) write about the flaws in the first Modigliani and Miller proposition and state that the cash flows of the firm are divided between debt holders, equity holders and the government, and that the capital structure of the firm that makes the most of its value will be the one that minimizes the portion of cash flows that go to the government in the form of taxes.

Kumaret et al (1999) in Buringuriza and Hyltenstam (2002) affirm that industries dependent on external finance tend to have smaller firms on average, indicating low growth and low performance, as do countries with decreasing financial development levels. They also state that equity financed industries develop gradually in states 
Effects of Capital Structure on Share Price Performance of Commercial Banks Listed in Nairobi ....

that are more developed financially and undertake less research and development. In contrast to what happens in the developed countries, bank where they are dependent industries in the countries with little Gross Domestic Product grow faster as the banking system develops. Empirical research done in Kenya and in other African states indicated that a company's debt to equity ratio has a significant impact on a firm's financial performance. Maina and Kodongo, (2013) carried out a study on the capital structure and its effects on the performance of financial listed firms in the Nairobi securities exchange. The study employed debt to equity ratio as one of the capital structure factors uses to measure leverage.

The findings indicate that there was an inverse but significant correlation between financial performance and debt to equity ratio of firms listed at the Nairobi securities exchange. These findings collaborate with the findings of Mwangi et al, (2014) where she examined the link between capital structure and performance of nonfinancial companies listed at the Nairobi securities exchange. The findings showed that, there existed a negative but significant link between financial performance and debt to equity ratio as established byreturn on assets (ROA) and return on equity. Kaumbuthu, (2011) carried out a study to assess the link between capital structure and return on equity for industrial sectors in the Nairobi securities exchange during the period of 4 years from 2004 to 2008. Capital structures were measured by debt to equity ratio (DER) while performance focused on return on equity (ROE).

The study employed regression analysis model and found a negative link between debt equity ratio (DER) and ROE. The study paid attention on only one sector of the organizations listed in Nairobi Securities Exchange (NSE) and concentrated on one aspect of financing decisions. The results of the study, therefore, were not generalized to the other sectors. Abor (2008) researched on the specific elements of the capital structure of Ghanaian firms listed on GSE (Ghana Stock Exchange) during the six-year period, 1998-2003. The results also revealed that both short and long-term and debt ratios were negatively related with profitability in all the groups that were sampled. The results of this study evidently supported and used the pecking order hypothesis, where profitable firms primarily are based on generated funds that are internally that are less costly and subsequently look for external resources if additional funds are need for investments.

Abdul, (2012) researched on the link between capital structure decisions with the performance of engineering firms and its sector of Pakistan, the results showed that monetary leverage established by debt that is short term to total assets and total debt to total assets had a significantly inverse correlation with the firm performance measured in terms of return on assets (ROA), and return on equity (ROE) had inverse but insignificant link with leverage. Firms in Pakistan within the engineering sector were mainly reliant on short term debt but were attached with strong agreements which affected the performance of the firms. This section critically reviewed literature with regard to equity; it is evident that most of the studies focus on firm performance and its relationships with other variables like debt and equity ratio, the literature have also been inclined to other areas away from the banking sector. This study therefore seeks to fill this gap and study on the effects of equity on share price performance in Kenyan banks listed in the NSE.

\subsubsection{Effect of Bonds on Share Price Performance}

Bonds are a form of debt presented by organizations to individual and institutional investors. Unlike stock, money brought in from the bonds sale should be paid back with interest exceeding a specific period of time. Bonds have fewer strings involved than stocks, however, since the organization's relationship ties with bondholders are completely severed at the end of the repayment period. According to Balduzzi, (2001), a bond is a debt instrument or a loan in which the terms, pay-back date and interest rates are detailed in a legal document. In finance, a bond is a debt security, in which the certified issuer be in debt of the holders a debt and is indebted to pay interest and repay the principal afterwards (Balduzzi, 2001).

Eckbo (1985) studies the stock effect to corporate debt offerings during the period 1964 through1981. He finds the two-day abnormal return to the initial bond issuance statement is significantly inverse. With the analysis of cross-sectional regression, the inverse stock price response is found having no association with the bond issue, particularly with the size of the issue. This result is inconsistent with the model of Asquith and Mullins (1986) where the offerings size has a negative link with the abnormal return stock.

Thiong'o (2012) sites both advancements made in the recent years towards trading of bonds at the NSE as well as hindrances that may have seen a below par subscription of corporate debt. Thiong'o further points to the oversubscription of two recent bond issues (KenGen, 2010 and Safaricom, 2011) and the subsequent profits recorded in the corresponding financial periods as an indication toward the link between firms issuing debt and an increased revenue. 
Effects of Capital Structure on Share Price Performance of Commercial Banks Listed in Nairobi ....

Gebhardtet al (2005), in their study, indicate that bonds and stocks have the same underlying operating cash flows and are affected by the same company fundamentals. In the study, it is shown that over a ninety day period, any abnormal returns on a company's stock matched by better performance of short term notes with floating interest rates. Therefore, bonds cannot progress separately of equities.

According to Barclay and Smith (2005), adding up more debt to an organization's capital structure can provide as a realistic signal of high expected upcoming cash flows. The managers of companies that have lifted their levels of debt are, in effect, signaling to the markets that they are attentive of the states of their companies, which are constructive, and they believe that the companies 'performances will enable them to disburse off their debts that are additional. The study shows that there is a positive link between the extent of leverage and the forecast performance of the stock of the firm.

Uwuigbeet al. (2012) examined the indicators of share prices in the stock exchange market in Nigeria. Using the sampling technique of judgmental, a total of 30 companies were selected and data (2006 to 2010) collected from the stock exchange and annual reports of the firms. The paper modeled the effects of dividend payout, financial leverage and financial performance on share price of listed firms by using regression analysis. The study concluded that dividend payout and financial performance had a significant optimistic link with share prices while financial leverage (proxied by debt-equity ratio) had significant negative influence on the market value of share prices in Nigeria.

Buigutet al. (2013) on their study on the link between capital structure and share prices in NSE assessed the effect of equity, gearing ratio and debt, equity on share price. Using data pertaining to the energy sector over the period 2006 till 2012 and employing multiple regression analysis, the results indicated that equity, gearing ratio and debt were significant elements of share prices for the sector under investigation. Further, debt and gearing ratio were found to aversely influence share prices while equity inversely affected share prices.

In Kenya, studies on the association between bond issue and share prices are scarce. Studies on bonds have been conducted by Mbugua (2003) who examined factors that influenced the development of the corporate bonds market in Kenya and his findings indicated that corporate bonds have high yields since interest payments were taxable. He therefore did not touch on the effect of bonds on share prices.

Ringui, (2012) is of the opinion that firms could be stimulated to perform better if the political and regulatory factors in the country are favorable for the corporate bond market to perform better. His study however, does not directly look at the relationship between this share price performance and any bond that they issue. There is little evidence of share price performance on announcement of bond issues due to conflicting findings in prior studies. There is therefore need for study to determine the link between bonds issues and movement in share prices of banks that issue both debt and equity securities. This therefore gives rise to a research question; "what is the effect of Bonds on Share Prices of firms listed at the Nairobi Securities Exchange?

\subsubsection{Effects of Retained Earnings on Share Price Performance}

Retained earnings which is also known as revenue reserves which as opined by Kim and Suh (2010) is the net income accumulated that is maintained by an organization instead of distributing to the shareholders as dividends, is one of the key retentions created by organizations. Retained earnings is the fraction of net profits that is not paid out as dividends, but the company retains to be reinvested in its main business or to pay debt

Dividend decision also involves the determination of the percentage of the profits/earnings of a company to pay out as dividend to the stakeholders/shareholders or retained within the self-financing firm (Onuorah and Ezeji 2013). Retained Earnings and the actual effects of monetary shocks was examined by Doepke (2004) and submitted that another key feature of an economy is that the business sector accumulates retained earnings and credits profits also dividends to the customers and other stakeholders only with a delay. This is because the bottom line can only be verified at the end of the accounting year leading to proposing the arrears in year's dividend, thus, the delay. The study concludes that retained earnings are of concern for the communication of monetary policy because they influence the overall balance between different uses of economy and that organizational profits respond faster to a monetary changes, whereas dividend payments adjust only after a significant delay.

Since the shareholders own the firms, in a frictionless model, they would consider retained earnings as equivalent to their own savings. Segal and Spivak (1986) conducted a study on maximum growth rate and firm size through retention reinvestment and the study concluded that by reinvesting them in the firm and retaining earnings and, the firm can amend the parameters governing the process, reducing the probability of disappearance and increasing the probability of multiplication and. Thus the decision of the firm variable is the amount of the retained earnings.

DOI: 10.9790/487X-180903122133

www.iosrjournals.org

126 | Page 
Effects of Capital Structure on Share Price Performance of Commercial Banks Listed in Nairobi ....

Daniel, Denis and Naveen (2007) did a study to confirm that organizations manage earnings that is increasing when they expect that earnings that are pre-managed will be lower than anticipated dividend payments. They found that firms whose discretionary accruals cause reported earnings to go beyond expected dividend stages are significantly less likely to hack dividends than are firms that have reported earnings that fall short of expected dividend stages. Collectively, they argue that their findings imply that managers take care of level of expected dividend as a significant earnings threshold. Thirumalaisamy (2013) studied on the associations between retained earnings and organizational growth and in India particular using correlation and multiple regressions approach. The study revealed that corporate firm's growth is significantly financed by retained earnings hence there is no bankruptcy costs or transaction associated with retained profits which made it the main internal source of finance for companies.

In his study on retained earnings and its impact on share price, Beisland (2014) determined that there is positive relation between stock price and retained earnings. However, according to a study by Khan and Zulfiqar (2012), there is no significant link between historical accounting numbers such as earnings and stock returns. However, Edmans et al. (2007) postulates that shareholders who invest in stocks expect that high earnings retention ratio will increase the growth of their company as well as the stock prices. Failure to grow revenues makes the investors to might not think that there are any advantages of earnings retentions (Ball, 2013). Also, Mohammad et al (2012)studied dividend policy and its influence of share price volatility in the Malaysian market showed a significant link which was negative between share price volatility with measurements of dividend policy which are dividend yield and dividend payout. In their study Mohammad et al.(2012)concludes that dividend size and dividend yield have most influence on share price volatility amongst stock price predictor variables. Therefore, while some theories postulate that there is association between dividend policy and stock returns, others are opposed of this proposition. Also, some empirical studies have revealed a positive strong link between dividend policy and stock returns. Yet, others established either a weak relationship, others a negative relationship and others established an insignificant link between the two variables. Also, most research focus on dividend payout and not earnings retentions. Also, most literatures exist on the effect of dividend payout on stock returns and not stock prices. This study therefore seeks to fill this gap and study the effect of retained earnings on share price performance.

\section{Materials And Methods}

The study employed a descriptive survey research design. The study targeted was 16 branch managers and 17 operations managers making a total of 33 respondents with a sample size of 33 respondents. The study used 5point likert questionnaires as the method data collection instruments. Cronbach's coefficient alpha was applied on the results obtained to establish relationships between variables; a cronbach alpha of 0.70 was obtained which confirmed the reliability of the research instruments

\subsection{Data Analysis}

The data collected was analyzed using descriptive methods and inferential statistics. Descriptive methods were used to analyze the data where mean and standard deviation were used in interpreting the results. Inferential methods such as Pearson test of association was used to show the link between capital structure and the share price performance. The regression model was used to determine the relationship between dependent and independent variables. SPSS was used to analyze the data. The findings from the analysis was organized, summarized and presented using tables.

Multiple regression and correlation analysis was used to determine the nature and significance of relationship between changes in the response variable and change in the predictor variables (determinants) identified in the study. The regression equation model was as below:

Where:

$$
\mathrm{Y}=\beta 0+\beta_{1} \mathrm{X}_{1}+\beta_{2} \mathrm{X}_{2}+\beta_{3} \mathrm{X}_{3}+\beta 4 \mathrm{X}_{4}+\varepsilon
$$

Y= Dependent Variable - (share price performance)

$\mathrm{X} 1=$ Debt Ratio (ratio of total debt to total assets)

$\mathrm{X} 2=$ Equity ratio

$\mathrm{X} 3=$ bonds

$\mathrm{X} 4=$ Retained earnings

$\beta 0=$ Constant

$\mathcal{E}=$ error term 


\subsection{Correlation results}

\section{Results And Discussion}

From the study Karl Pearson's coefficient correlation was employed to test the extent of correlation between variables, Hair et al., (2010) states that there should be a high correlation between the dependent variable(s) and the independent variables, while the independent variables exhibit low correlation with each other, from the study Investigation on the amount of linear relationship between Debts, Equity, Bonds, Retained earnings and Share Price Performance showed a positive coefficient of Debts 0.400, Equity 0.000, Bonds 0.00, and Retained earnings 0.00 which was significant at 0.01 level. This result indicates that the independent variables of the study (Debts, Equity, Bonds and Retained earnings) move in the same direction as the share value price in commercial banks listed in the Nairobi Security Exchange. Thus the relationship established is that as the level of share value price improves or increase, the higher the chance that Equity, Bonds and Retained earnings develops in the banks. Table 1.0 gives the entire raw results as obtained from the data analysis.

Table 1.0 Correlation between Debts, Equity, Bonds, Retained earnings and Share Price Performance

\begin{tabular}{|ll|l|l|l|l|l|}
\hline & & Debts & Equity & Bonds & $\begin{array}{l}\text { Retained } \\
\text { eamings }\end{array}$ & $\begin{array}{l}\text { Share } \\
\text { Performance }\end{array}$ \\
\hline \multirow{2}{*}{ Debts } & Pearson Correlation & 1 & .044 & .043 & .098 & .160 \\
& Sig. (2-tailed) & & .816 & .823 & .605 & .400 \\
& Pearson Correlation & .044 & 1 & $.447^{*}$ & $.754^{* *}$ & $.818^{* *}$ \\
Bonds & Sig. (2-tailed) & .816 & & .013 & .000 & .000 \\
& Pearson Correlation & .043 & $.447^{*}$ & 1 & $.384^{*}$ & $.641^{* *}$ \\
Retained & Sig. (2-tailed) & .823 & .013 & & .036 & .000 \\
eamings & Pearson Correlation & .098 & $.754^{* *}$ & $.384^{*}$ & 1 & $.794^{* *}$ \\
Share Price (2-tailed) & .605 & .000 & .036 & & .000 \\
Performance & Searson Correlation & .160 & $.818^{* *}$ & $.641^{* *}$ & $.794^{* *}$ & 1 \\
\\
*. Correlation is significant at the 0.05 level (2-tailed). \\
**. Correlation is significant at the 0.01 level (2-tailed).
\end{tabular}

\subsection{Model Summary}

From the results on model summary $\mathrm{R}=0.929$, $\mathrm{R}$ - square $=0.863$, adjusted $\mathrm{R}$ - square $=0.841$, and the $\mathrm{SE}=$ 0.183 . Multiple correlation $\mathrm{R}$ coefficients indicate the degree of linear relationship of the dependent variable (share price performance) with all the predictor variables, whereas the coefficient of multiple determinations R-square shows the provision of the total variation in firms share price that is explained by the independent variables, retained earnings, debts, bonds, and equity in the regression equation. The R-square gives us the coefficient of determination between the variables the results from the regression analysis give an R-square value of 0.863 , which means that $86.3 \%$ of the independent variables cause the change on dependent variable (share price).

Table 1.1 Model Summary

\begin{tabular}{|l|l|l|l|l|}
\hline Model & $\mathrm{R}$ & R Square & Adjusted R Square & Std. Error of the Estimate \\
\hline 1 & $.929^{\mathrm{a}}$ & .863 & .841 & .183 \\
\hline
\end{tabular}

\subsection{Analysis of Variance (ANOVA)}

The significance of the regression model was tested using Analysis of Variance (ANOVA). Table 1.2 below presents the results of this test. The regression model also indicated that it was significant $(\mathrm{p}=.000)$ to mean that it had not been computed by chance, this was because the significance value is 0.000 which is less than 0.05.This made the results of the regression model credible and reliable.

Table 1.2 Analysis of Variance ANOVA ${ }^{\mathrm{a}}$

\begin{tabular}{|l|l|l|l|l|l|l|}
\hline Model & Sum of Squares & Df & Mean Square & F & Sig. \\
\hline \multirow{3}{*}{1} & Regression & 5.262 & 4 & 1.315 & 39.253 & $.000^{\mathrm{b}}$ \\
\cline { 2 - 6 } & Residual & .838 & 25 & .034 & & \\
\cline { 2 - 6 } & Total & 6.099 & 29 & & & \\
\hline \multicolumn{2}{|l|}{ a. Dependent Variable: Share Price Performance } \\
\hline \multicolumn{2}{|l}{ b. Predictors: (Constant), retained earnings , debts , bonds, equity } \\
\hline
\end{tabular}




\subsection{Regression analysis}

The study adopted the simple regression model to evaluate how each of the study hypotheses

$\mathbf{H O}_{1}$ : There is no significant relationship between debts and share price performance in the banks listed in the NSE.

$\mathbf{H O}_{2}$ : There is no significant relationship between equity and share price performance in the banks listed in the NSE.

$\mathbf{H 0}_{3}$ : There is no significant relationship between bonds and share price performance in the banks listed in the NSE.

$\mathbf{H O}_{4}$ : There is no significant relationship between retained earnings and share price performance in the banks listed in the NSE.

The results were illustrated in the following regression output tables;

$\mathrm{HO}_{1}$ : There is no significant relationship between debts and share price performance in the banks listed in the NSE.

A simple multiple regression model was used to test for the relationship between the independent variables (debts) and dependent variable (share price performance). As shown in table 1.3 below

Table 1.3 Coefficients of debts and share price performance

\begin{tabular}{|c|l|l|l|l|l|l|}
\hline \multicolumn{2}{|l|}{ Model } & Unstandardized Coefficients & Standardized Coefficients & t & Sig. \\
\cline { 3 - 7 } \multicolumn{2}{|l|}{} & B & Std. Error & Beta & & \\
\hline 1 & (Constant) & 3.537 & .610 & & .798 & .000 \\
\cline { 2 - 7 } & Debts & .128 & .150 & .160 & .855 & .400 \\
\hline \multicolumn{2}{|l|}{ a. Dependent Variable: Share Price Performance } \\
\hline
\end{tabular}

From the 1.3 the simple linear regression results indicates that there was a linear relationship between the debts and share price performance of commercial banks listed in the NSE in that, $12.8 \%$ of the variation in debts is explained by $87.2 \%$ of the variation in share price performance. This was further supported by a $\mathrm{p}$ value of 0.400 , The results from the findings supports that higher debt ratios could lead to optimistic management expectations and is associated with future cash flows. This therefore means that debt may result to shifts in the share prices of securities in a firm and hence have a general influence on the share price performance of a firm. Also Majumdar and Chhibber (1999) found significantly negative effect of level of debt on firm performance

$\mathrm{HO}_{2}$ : There is no significant relationship between equity and share price performance in the banks listed in the NSE.

A simple multiple regression model was used to test for the relationship between the independent variables (equity) and dependent variable (share price performance). As shown in table 1.4 below

Table 1.4 Coefficients of equity and share price performance

\begin{tabular}{|c|c|c|c|c|c|c|}
\hline \multirow{2}{*}{\multicolumn{2}{|c|}{ Model }} & \multicolumn{2}{|c|}{ Unstandardized Coefficients } & Standardized Coefficients & \multirow[t]{2}{*}{$\mathrm{t}$} & \multirow[t]{2}{*}{ Sig. } \\
\hline & & B & Std. Error & Beta & & \\
\hline \multirow[t]{2}{*}{1} & (Constant) & 1.778 & .306 & & 5.801 & .000 \\
\hline & Equity & .556 & .074 & .818 & 7.524 & .000 \\
\hline
\end{tabular}

From the table 4.15, the simple linear regression results indicates that there exist a positive linear relationship between equity and share price performance in that, 55.6\% of the variation in equity is explained by share price performance. This is further supported by a p value of 0.000 which is less than the significant value of 0.05. These finding are supported by Abdul, (2012) researched on the link between capital structure decisions with the performance of engineering firms and its sector of Pakistan, the results showed that monetary leverage established by debt that is short term to total assets and total debt to total assets had a significantly correlation with the firm performance measured in terms of return on assets

$\mathrm{HO}_{3}$ : There is no significant relationship between bonds and share price performance in the banks listed in the NSE.

A simple multiple regression model was used to test for the relationship between the independent variables (bonds) and dependent variable (share price performance). As shown in table 1.5 below

Table 1.5 Coefficients of bonds and share price performance

\begin{tabular}{|c|c|c|c|c|c|c|}
\hline \multirow{2}{*}{\multicolumn{2}{|c|}{ Model }} & \multicolumn{2}{|c|}{ Unstandardized Coefficients } & \multirow{2}{*}{$\begin{array}{l}\text { Standardized Coefficients } \\
\text { Beta }\end{array}$} & \multirow[t]{2}{*}{$\mathrm{t}$} & \multirow[t]{2}{*}{ Sig. } \\
\hline & & B & Std. Error & & & \\
\hline \multirow[t]{2}{*}{1} & (Constant) & 2.134 & .440 & & 4.849 & .000 \\
\hline & Bonds & .481 & .109 & .641 & 4.413 & .000 \\
\hline
\end{tabular}

DOI: 10.9790/487X-180903122133

www.iosrjournals.org 
From the table 1.5, the simple linear regression results indicates that there exist a positive linear relationship between bonds and share price performance in that, $48.1 \%$ of the variation in bonds is explained by share price performance. This is further supported by a p value of 0.000 which is less than the significant value of 0.05. These finding are supported by KenGen, (2010) and Safaricom, (2011) which stated that the subsequent profits recorded in the corresponding financial periods as an indication toward the link between firms issuing debt and an increased revenue.

According to Barclay and Smith (2005), stated that adding up more debt to an organization's capital structure can provide as a realistic signal of high expected upcoming cash flows. The managers of companies that have lifted their levels of debt are, in effect, signaling to the markets that they are attentive of the states of their companies, which are constructive, and they believe that the companies' performances will enable them to disburse off their debts.

Further Mbugua (2003) who examined factors that influenced the development of the corporate bonds market in Kenya and his findings indicated that corporate bonds have high yields since interest payments were taxable. He therefore did not touch on the effect of bonds on share prices.

$\mathrm{Ho}_{4}$ : There is no significant relationship between retained earnings and share price performance in the banks listed in the NSE

A simple multiple regression model was used to test for the relationship between the independent variables (retained earnings) and dependent variable (share price performance). As shown in table 1.6 below

Table 1.6 Coefficients of retained earnings and share price performance

\begin{tabular}{|c|c|c|c|c|c|c|}
\hline \multirow{2}{*}{\multicolumn{2}{|c|}{ Model }} & \multicolumn{2}{|c|}{ Unstandardized Coefficients } & Standardized Coefficients & \multirow[t]{2}{*}{$\mathrm{t}$} & \multirow[t]{2}{*}{ Sig. } \\
\hline & & B & Std. Error & Beta & & \\
\hline \multirow[t]{2}{*}{1} & (Constant) & 2.226 & .270 & & 8.248 & .000 \\
\hline & retained earnings & .462 & .067 & .794 & 6.902 & .000 \\
\hline
\end{tabular}

From the table 1.6, the simple linear regression results indicates that there exist a positive linear relationship between bonds and share price performance in that, $46.2 \%$ of the variation in bonds is explained by share price performance. This is further supported by a $p$ value of 0.000 which is less than the significant value of 0.05. These finding are supported by Kim and Suh (2010) is the net income accumulated that is maintained by an organization instead of distributing to the shareholders as dividends, is one of the key retentions created by organizations. Additionally Daniel, Denis and Naveen (2007) did a study to confirm that organizations manage earnings that is increasing when they expect that earnings that are pre-managed will be lower than anticipated dividend payments. They found that firms whose discretionary accruals cause reported earnings to go beyond expected dividend stages are significantly less likely to hack dividends than are firms that have reported earnings that fall short of expected dividend stages. Thirumalaisamy (2013) stated that corporate firm's growth is significantly financed by retained earnings hence there is no bankruptcy costs or transaction associated with retained profits which made it the main internal source of finance for companies.

Table 1.7 Regression coefficients of the relationship debts, equity, bonds, retained earnings and share price performance

\begin{tabular}{|c|c|c|c|c|c|c|}
\hline \multicolumn{2}{|c|}{ Model } & \multicolumn{2}{|c|}{ Unstandardized Coefficients } & \multirow{2}{*}{$\begin{array}{l}\text { Standardized Coefficients } \\
\text { Beta }\end{array}$} & \multirow[t]{2}{*}{$\mathrm{T}$} & \multirow[t]{2}{*}{ Sig. } \\
\hline & & B & Std. Error & & & \\
\hline \multirow[t]{5}{*}{1} & (Constant) & .474 & .356 & & 1.331 & .195 \\
\hline & Retained earnings & .253 & .067 & .435 & 3.768 & .001 \\
\hline & Debts & .162 & .061 & .202 & 2.661 & .013 \\
\hline & Equity & .226 & .081 & .332 & 2.795 & .010 \\
\hline & Bonds & .250 & .063 & .333 & 4.005 & .000 \\
\hline
\end{tabular}

The findings presented in table 1.7 above shows that taking all other independent variables constant, a unit increase in Retained earnings will lead to a 0.253 increase in share price performance; a unit increase in debts will lead to a 0.162 increases in share price performance, a unit increase in equity will lead to a 0.226 increases in share price performance and a unit increase in bonds will lead to a 0.250 increase in share price performance.

Further, it is indicated that all the four predictor variables (debts, equity, bonds and retained earnings) showed a strong relationship with the dependent variable (share price performance). Thus the regression equation becomes; 


\author{
$Y=0.474+0.253 X_{1}+0.162 X_{2}+0.226 X_{3}+0.250 X_{4}+\square$ \\ Where: \\ $\mathrm{Y}=$ Dependent Variable - (share price performance) \\ $\mathrm{X} 1=$ Debt Ratio (ratio of total debt to total assets) \\ $\mathrm{X} 2=$ Equity ratio \\ $\mathrm{X} 3=$ bonds \\ $\mathrm{X} 4=$ Retained earnings
}

\title{
V. Conclusion
}

From the study it was concluded that borrowing money increases the debt ratio thus affect the performance of the share price, increasing the debt ratio may reduce a firm's cost of capital, Minimizing the cost of capital maximizes the debt ratio which positively affects the share price performance, more over debt ratios leads to optimistic management expectations and probable future cash flows. This is supported by the theory of pecking order proposed by Myers (1984). The theory states that firms favor internal finance sources; they employ their target dividend payout ratios to their investment opportunities although payout ratios and dividends are gradually familiar to shifts in the degree of important investment opportunities. In addition, Myers (1984) stated that in the event that external finance is required, firms are mainly possible to offer safe security first that is to say they begin with debt then possibly convertible debt then equity comes as last resort. Myers' argument was such that businesses stick to a hierarchy of financing sources and prefer internal financing when available. Should external financing be required, debt would be preferred over equity. To add that the theory of pecking order was able to explain the negative link connecting debt ratio and profitability within an industry however; the theory did not entirely explain the capital structure differences between industries.

On the effects of equity on share price it was concluded that Equity financing carries less risks promoting shareholder investment, New shares offered to the current shareholder have a rebated price which attracts investment, further the decrease in share price of a new equity issue depends on the firms ownership structure and shareholders' equity is used in equity valuation to determine what return is being generated by the company. This is supported by the Modigliani and Miller theory which proposes that the cash flows of the firm are divided between debt holders, equity holders and the government, and that the capital structure of the firm that makes the most of its value will be the one that minimizes the portion of cash flows that go to the government in the form of taxes. Further Buringuriza and Hyltenstam (2002) further affirms that industries dependent on external finance tend to have smaller firms on average, indicating low growth and low performance, as do countries with decreasing financial development levels

Regarding the effects of bonds on share price performance, it was concluded that corporate bonds have high yields since interest payments are taxable, Bond market can lead to a healthier banking system by improving market discipline, Bonds compensate the fluctuations in the overall supply of external funds hence improving the economic cycle and bond issuance helps banks achieve steady economic growth as it shows less pronounced cyclical patterns than bank loans, this is supported by Gebhardtet al (2005), in their study, indicate that bonds and stocks have the same underlying operating cash flows and are affected by the same company fundamentals. Further Balduzzi, (2001), who stated that a bond is a debt instrument or a loan in which the terms, pay-back date and interest rates are detailed in a legal document. In finance, a bond is a debt security, in which the certified issuer be in debt of the holders a debt and is indebted to pay interest and repay the principal afterwards.

On the effects of retained earnings it was concluded that, retained earnings increases the supply of cash that's available for acquisitions, re purchase of outstanding shares, also retained earnings can be utilized to create value for the shareholders, further Retained earnings are readily available for use and are cheaper than external equity hence the perception potential investment opportunities and finally retained earnings boost the company's value and, in turn, boost the value of the amount of money you invest into it. This is supported by the ModiglianiMiller Theory, which states that all agents know the distribution of returns of the firm, but only the firm privately and cost less assess the ex-post of the return. The lender can get this information, but must irreversibly commit to pay a huge verification cost. Townsend (2011) postulates that debt is most favorable because it leads to cost minimization. When the firm creates the necessary fixed debt repayment, there is no cost that is incurred.

Lastly it was concluded that financial decisions enhance performance of shares at Nairobi Securities Exchange, thus increasing investor's confidence, also capital structure decisions are critical as a shift in leverage could increase or decrease the financial strains on companies share prices, further an increase in debts leads to an increase in a companies' share price, availability of cheap debt enables firms to take advantage of cheap credit for expansion and profitable investments. This is supported by Mensah(2001) who states that a firm's capital structure is 
Effects of Capital Structure on Share Price Performance of Commercial Banks Listed in Nairobi ....

a composition or structures of its liabilities which affects the share prices performance of any organization. The level of share price has been considered very significant specifically as an alternative for market liquidity. Investment in securities is also significant to expansion a country's economy and corporate bodies in general. If there is a developed economic environment and managers and stakeholders in the corporate level have the positive expectations about the future, they would normally want to expand. Kheradyar and Ibrahim (2011) also states that share price is usually used as a benchmark to gauge firm's performance and its variations as an pointer of the economic status, or otherwise, of a firm hence the need to be well-known with the indicators that could negatively affect share prices

\subsection{Recommendation of the Study \\ 5.1.1 Recommendation with Policy and Practice}

The study recommends that on the effect of debt on share price performance, the commercial banks listed in Nairobi Security Exchange should formulate and enact a policy which makes commercial debt cheaper hence reduces cost of operations of banks. In this way the banks will be able to acquire more financing through acquisition of debt which will help in improving working capital and subsequently their performance.

On the effects of equity on share price performance in banks listed in the NSE, the banks should keep its capital structure low if the management is likely to confront an uncertain environment but how low or how high is the basic question. This is because capital structure capital structure plays a role in determining the risk level of the company.

Further, on effect of bond on share price performance in the banks listed in the NSE it is recommended that banks should add up more debt to their capital structure, this can provide a realistic signal of high expected upcoming cash flows and also signals to the markets that the bank are attentive of the states of their companies, which are constructive, and they believe that the companies' performances will enable them to disburse off their debts.

Lastly the study concluded that, retained earnings increases the supply of cash that's available for acquisitions, re purchase of outstanding shares, also retained earnings can be utilized to create value for the shareholders, further Retained earnings are readily available for use and are cheaper than external equity hence the perception potential investment opportunities, thus it is recommended that listed Banks should intensify their efforts to rely on internally generated funds to finance their operational activities.

\subsubsection{Recommendation for Further Research}

Since the study focused on the financial institutions listed in the Nairobi securities exchange which is only one sector of the 12 sectors. It is recommended therefore that another research is required to examine the effects of capital structure on share price of the firms in the different sectors. The further research will complement the findings of this study by providing information on the determinants of share price performance.

\section{References}

[1] Abdul G. (2012) the relationship of capital structure decisions with firm performance: A study of the engineering sector of Pakistan. International Journal of Accounting and Financial Reporting, 2(1). 2162-3082

[2] Abor, J. (2005). The effect of capital structure on profitability: an empirical analysis of listed firms in Ghana. [Article].Journal of Risk Finance (Emerald Group Publishing Limited), 6(5), 438-445.

[3] Akerlof, A., (1970), The Market for 'Lemons': Quality Uncertainty and the Market Mechanism. Quarterly Journal of Economics 84: 488500.

[4] Ball, R. (2013). Accounting Informs Investors and Earnings Management is Rife: Two Questionable Beliefs. Accounting Horizons, 27(4), 847-53.

[5] Barclay, M., \& Smith C. W. (2005) The maturity structure of cooperate debt. Journal of Finance,50(3), 609-631.

[6] Beisland, L. A. (2014). Equity Valuation in Practice: The Influence of Net Financial Expenses. Accounting Forum, 38, 122-131.

[7] Brealey R. A. and Myers S. C. (2003).Principles of Corporate Finance. International Edition. McGraw-Hill, 7 edition, 2003. 40

[8] Buigut, K. Soi, N. Koskei, I. \&Kibet, J. (2013).The Effect of Capital Structure on SharePrice on Listed Firms in Kenya. A Case of Energy Listed Firms. European Journal of Business and Management, Vol. 5, No. 9, 2013

[9] Buringuriza, Emmanuel and Hltenstam, Johan (2002); Capital Market Development in Uganda - Statistical Profile of the Securities Market, Financial Systems Development (FSD) Programme

[10] Coricelli, F. andDriffield, N. and Pal, S. and Roland, I. (2012), "When does leverage hurt productivity growth? A firm-level Analysisq", Journal of International Money and Finance, No. 31, pp. 1674-1694

[11] Daniel, N., Denis, D. \& Naveen, L. (2007).Do Firms Manage Earnings to Meet Dividend Thresholds? Journal of Accounting and Economics www.elsevier.com/locate/jae 45 (2008) 2-26

[12] Doepke, M. (2004).Show Me the Money: Retained Earnings and the Real Effects of Monetary Shocks ,http://sites.uclouvain.be/econ/DP/REL/2005011.pdf

[13] Eckbo, B. E. (1985). Valuation effects of corporate debt offerings. Journal of Financial Economics, (15) 119-151.

[14] Edmans, A., Garcia, D., \& Norli, Ø. (2007). Sports sentiment and stock returns. Journal of Finance,62, 1967-1998 
[15] Gebhardt, A.C., Gaye-Haake, B., Unger, D., Lahajnar, N., Ittekkot, V., 2004. Recent particulate organic carbon and total suspended matter fluxes from the $\mathrm{Ob}$ and Yenisei estuaries into the Kara Sea (Siberia). Marine Geology 207, 225 e245

[16] Hair, J. F., Black, W. C., Babin, B. J., \& Anderson, R. E. (2010). Multivariate data analysis (7th ed.). Upper Saddle River, NJ: Prentice Hall.

[17] Harris, M. \&Raviv, A. (1991).The theory of capital structure. Journal of Finance, 46, 297- 355.

[18] Jensen, M. C. \& Meckling, W.H. (1986).Theory of the Firm: Managerial Behavior, Agency Costs and Ownership Structure, Journal of Financial Economics,3(4), 305-360.

[19] Kaumbuthu, A. J. (2011). The relationship between capital structure and financial performance: a study of firms listed under industrial and allied sector at the NSE,(MBA Dissertation, university of Nairobi.

[20] Khan, A. B., \& Zulfiqar, A. S. (2012).The Impact of Retained and Distributed Earningson Future Profitability and Stock Returns in Pakistan. International Research Journal of Finance and Economics, 121-32.

[21] Kheradyar, I. Ibrahim, and F. Mat Nor, (2011). Stock Return Predictability with Financial Ratios. International Journal of Trade, Economics and Fiance, 2(5): 391-396. J. Y.

[22] Kim Y. C., \&Stulz, R. M. (1992). Is there a global market for convertible bonds? Journal of Business, 65(1), 75-91.

[23] Kochhar, R., 1997. "Strategic assets, capital structure, and firm performance," Journal of Financial and Strategic Decisions, Vol.10, No3, pp.23-36.

[24] Kyereboah-Coleman, A. (2007). The impact of capital structure on the performance of microfinance institutions.[Article].Journal of Risk Finance (Emerald Group Publishing Limited), 8(1), 56-71

[25] Machel Ngure (2013) The Effect Of Bond Issue On Share Prices Of Firms Listed At The Nairobi Securities Exchange, Unpublished MBA Project, University of Nairobi.

[26] Majumdar, Sumit K.; Chhibber, Pradeep; (1999). "Capital structure and performance: Evidence from a transition economy on an aspect of corporate governance." Public Choice 98 (3-4): 287-305.

[27] Mbugua M.M., (2003). Factors Influencing Development of the Corporate Bond Market in Kenya, Unpublished MBA Project, University of Nairobi

[28] Mensah, S. (2004). A Review of SME Financing Schemes in Ghana. Paper presented at the UNIDO Regional Workshop of Financing Small and Medium Scale Enterprises, Accra, Ghana.

[29] Miller, M.,\& Rock, K. (1985).Dividend policy under asymmetric information. Journal of Finance, 40(4), 1031-1051

[30] Mohammad, H., Ardekani, A. M., \&Younesi, N. (2012). The Impact of Dividend Policy on Share Price Volatility in the Malaysian Stock Market. Journal of Business Studies Quarterly, 4(1), 111-29

[31] Mwangi C.I, Anyango M.O, \& Amenya S, (2012). Capital Structure Adjustment, speed of Adjustment and Optimal Target Leverage among firms quoted in Nairobi Stock Exchange. International Journal for Humanities and Social Sciences.

[32] Myers S., Majluf, (1984), corporate financing and investment decision when firms have information that investors do not have, Journal of Financial Economics, 13(2), 187-221

[33] Ondiek, B. (2010). The relationship between capital structure and financial performance of firms listed at NSE. (Unpublished MBA). University of Nairobi, Nairobi.

[34] Onuorah, A., \&Ezeji, E.C.(2013). A Comparative Analysis of the Impact of Corporate Taxation OnCompany's Reserve and Dividend Policy in Nigeria: 2000-2011, Developing Country study, International Knowledge Sharing Platform, 3(1).

[35] Ringui, J. K. (2012). A survey of factors determining development of corporate bonds market in Kenya. Kenyatta University MBA Publication, 18-19, 22-25.

[36] Ross, Stephen A. (1977). "The determination of financial structure: the incentive-signaling approach." The Bell Journal of Economics: 23-40

[37] Saad, N. M. (2010). Corporate Governance Compliance and the Effects to Capital Structure. International Journal of Economics and Financial, 2(1), 105-114.Safaricom, (2011)

[38] Segal, U \& Spivak, A. (1985).Firm Size and Optimal Growth Rates, UCLA Working Paper380,Applied Economics and Finance

[39] Shuetrim, Geoffrey and Lowe, Philip and Morling, Steve(1993); The Determinants of Corporate Leverage: A Panel Data Analysis, RBA Research Discussion Papers, RDP 9313

[40] Thiong"o, P. (2012, September 28th). Bonds Selling Fast In Kenya. The East African, Issue 38(2012).28- 29.

[41] Thirumalaisamy, R. (2013). Firm Growth and Retained Earnings Behavior - A Study on Indian Firms, European Journal of Business and Management, 5(27)

[42] Uwuigbe, O., T.O. Fagbemi and U.F. Anusiem, 2012. The effects of audit committee and ownership structure on income smoothening in Nigeria. Research Journal of Finance and Ac counting, 3(4): 26- 33 